Management Theory and Studies for Rural Business and Infrastructure Development

eISSN 2345-0355. 2021. Vol. 43. No. 1: 151-160

Article DOI: https://doi.org/10.15544/mts.2021.13

\title{
MANAGEMENT OF ECONOMIC SECURITY OF INDUSTRIAL ENTERPRISES FOR COUNTERING RAIDING
}

\author{
Mykola Pisarevskiy ${ }^{1}$, Viktoriia Aleksandrova ${ }^{2}$,Viktoriia Yevtushenko ${ }^{3}$, Stanislav Poroka ${ }^{4}$, Vasyl \\ Shoiko ${ }^{5}$, Nadiia Karpeko 6
}

${ }^{1}$ PhD in Economics, V. N. Karazin Kharkiv National University, Kharkiv, Ukraine

${ }^{2}$ Candidate of Sciences (Economics), National Technical University, Kharkiv Polytechnic Institute, Kharkiv, Ukraine

${ }^{3}$ PhD in Economics, V. N. Karazin Kharkiv National University, Kharkiv, Ukraine

${ }^{4}$ Academic and Research Work Centre under the National University of Civil Defence of Ukraine, Kharkiv, Ukraine

${ }^{5}$ PhD in History, Associate Professor, National University of Civil Defence of Ukraine, Kharkiv, Ukraine

${ }^{6}$ PhD in Public Administration, National University of Civil Defence of Ukraine, Kharkiv, Ukraine

Received 1902 2021; Accepted 01032021

\begin{abstract}
Modern views on the economic nature of countering raiding is the important prerequisite for the enterprises stable development and the formation of the management system for their economic security based on the assessment and analysis of the environmental factors impact on the risk level of raider take-over. The presented article is aimed at the using analytical and methodological tools to identify the cause-and-effect relationships between environmental factors and the strength of their influence on the risk of raider take-over in order to be introduced into the activities of the enterprise to manage the economic security in the context of countering raiding.In this study, based on the method of analyzing hierarchies, the level of influence of the environmental factors (international, macroeconomic, strategic) of the threat of raider take-over of Ukrainian machine-building enterprises is established. The results confirmed the importance of substantiating of the environmental factors influence on the risk of a raider attack in order to develop the effective scenarios for preventing raider take-over through the prism of the problems of the economic security managing of the machine-building enterprises in rhe countries with economies in transition.
\end{abstract}

Keywords: risk; raiding; security; modeling; management; forecasting; efficiency; usefulness.

JEL Classification: D21, D29, O12.

\section{Introduction}

The problems solving to ensure economic security of industrial enterprises in modern conditions is possible only by the existing management system transforming on the basis of the introduction of the effective tools for protecting and countering raider takeover. The strengthening of the influence of global relations and the processes of integration of the domestic economy into the world economic space made it necessaary to develop the basic principles for ensuring economic security to counter raiding which allows machine-building enterprises to achieve the strategic goals (Nazarova et al., 2020).
Today, raiders show a high level of interest in the industrial sector of the economy, in particular in machine-building enterprises, due to the deteriorating financial condition (Ilkova, Rynkevych, 2018; Tamosiuniene, Demianchuk, Koval, 2019), imperfection of the current legislation in the field of corporate governance and the low level of protection of the property institution. The formation of the effective mechanism for the economic security management of industrial enterprises to counter raiding is based on a fundamental change in approaches for assessing the impact of the external and internal environmental factors to economic security and a timely response to the raiders aggressive actions

Copyright (C 2021 Author(s), published by Vytautas Magnus University. This is an open access article distributed under the terms of the Creative Commons Attribution Non-Commercial 4.0 (CC BY-NC 4.0) license, which permits unrestricted use, distribution, and reproduction in any medium provided the original author and source are credited. The material cannot be used for commercial purposes. 
which will ensure the adoption of informed management decisions and their effectiveness in the direction of raider take-over. Based on the perspective directions of the strategy for managing economic security in the process of countering raiding with the modern tools using of the economic and analytical analysis, there is an immediate need for implementation in the activities of the enterprises in Ukraine.

\section{Literature review}

The main purpose of the study of economic security of industrial enterprises in the direction of counteracting raiding should be to find the optimal ways to arise and prevent the external and internal risks and coordinate the decision-making and implementation of the balanced management decision which will create the basis for purposeful, systematic and adequate counteraction to raider seizure sadoption and implementation of prudent management decisions, which will create a purposeful, systematic and adequate counteraction to raider take-over (Varnaly, 2011). The leading scientists of Ukraine and other countries of the world are constantly interested in the management problems of the enterprises economic sacurity in the direction of countering raiding.

Heets, Kyzym and Klebanova (2006) emphasize the importance of ensuring economic security as it creates the basis for the sustainable functioning and development of the enterprise through the timely mobilization and most rational use of labor, financial, technical, technological and other resources of the enterprise under the influence of external and internal threats. Liashenko (2011) works substantiate the theoretical and methodological principles of forming a mechanism for ensuring economic security which allowed to develop some elements of the mechanism for the forming economic security in terms of countering raiding of the enterprises. Dreher and Schneider (2005) analyze the link between the black economy and corruption and raiding, highlighting the shortcomings of the existing legal system in high-income countries. Kuzmynchuk (2018) examines the institutional aspect of ensuring economic security in the system of the state regulation of entrepreneurship in the global and local aspects and creates the conditions for the development of a solid state policy in the field of protecting the property interests of business entities. Derevyanko (2020) identifies the means of counteracting and overcoming «raiding» by implementing certain measures at the state level to increase the level of protection of enterprises from «raider» attacks through the introduction of a register containing attempts and cases of raider attacks on property and corporate business rights.

Given the high level of the raiders interest in the industrial sector of the economy in order to solve the problem of preventing the risks of hostile takeover and the threats to the economic security of the industrial enterprises, it is necessary to form the analytical and applied toolkit for defining impact of the enterprise environmental factors on the risk of raider take-over for the implementation of the sound management decisions in the aspect of ensuring the economic security of machinebuilding enterprises.

\section{Results and discussion. Modeling the possibility of the raider takeover}

Economic security management of industrial enterprises to counter raiding provides for hostile take-over risk. Modeling the possibility of a raider takeover involves not only the actions aimed at assessing and analyzing the factors, the parameters and components of the constituting the raider suitability of the enterprise and also the management must predict in advance and prevent take-over all risk of the industrial enterprise. The management decisions formation to ensure the economic security of the industrial enterprise is based on the determination of a diagnostic indicator - signs of a probable raider take-over (risk), the range of its change in the forecast period, taking into account the degree of influence of threats The realization of this task is possible by means of cognitive modeling, provides for the implementation of a number of actions of the 


\section{Sciendo}

Management Theory and Studies for Rural Business and Infrastructure Development

eISSN 2345-0355. 2021. Vol. 43. No. 1: 151-160

Article DOI: https://doi.org/10.15544/mts.2021.13

analytical nature as well as the computational operations in accordance with a given general algorithm, including several stages of the research, grouped into three blocks of procedures. of The scientific literature generalization made it possible to single out the stages of modeling the possibility of raider take-over using cognitive imitation technologies, which are shown in Figure 1.

\section{Figure 1. Modeling stages of the possibility of raider take-over through the cognitive} simulation technologies using

\begin{tabular}{|c|c|c|}
\hline \multicolumn{3}{|c|}{ PREPARATORY STAGE - Cognitive analysis of information } \\
\hline $\begin{array}{l}\text { Target setting } \\
\text { stage }\end{array}$ & $\begin{array}{l}\text { Setting the main goal and the further } \\
\text { research; } \\
\text { goals of object definition. }\end{array}$ & $\begin{array}{l}\text { Formation of the goal or goal tree; the selection of } \\
\text { the research areas; the definition of the control } \\
\text { subsystems, their processes. }\end{array}$ \\
\hline \multicolumn{3}{|c|}{ MAIN STAGE - Cognitive modeling } \\
\hline $\begin{array}{l}\text { The first } \\
\text { research stage }\end{array}$ & $\begin{array}{l}\text { Analysis of the factors that characterize the } \\
\text { development of the object of the basis of } \\
\text { cognitive structured knowledge }\end{array}$ & $\begin{array}{l}\text { Identification of the factors that characterize the } \\
\text { development of the object; grouping of these factors } \\
\text { by blocks: the basic factors, factors-indicators, } \\
\text { factors-levers of influence. }\end{array}$ \\
\hline $\begin{array}{l}\text { The second } \\
\text { research } \\
\text { stage. }\end{array}$ & $\begin{array}{l}\text { The determination of cause-effect } \\
\text { relationships between the factors and the } \\
\text { strength of their influence on each other; } \\
\text { the construction of a cognitive map or a } \\
\text { signed directed graph in the form of an } \\
\text { adjacency matrix }\end{array}$ & $\begin{array}{l}\text { The determination of the positivity of the influence } \\
\text { (an increase/decrease in the } i \text {-th factor will lead to } \\
\text { an increase/decrease in the } j \text {-th factor }-" 1 " \text { ); the } \\
\text { determination of the negativity (visibility of the } \\
\text { influence (an increase/decrease in the } i \text {-th factor will } \\
\text { lead to a decrease/increase in the } j \text {-th factor - "0"). }\end{array}$ \\
\hline \multicolumn{3}{|c|}{ RESULTING STAGE - The development scenarios construction } \\
\hline $\begin{array}{l}\text { The final stage } \\
\text { of the research }\end{array}$ & $\begin{array}{l}\text { Conducting scenario analysis based on the } \\
\text { establishment of pulse processes in the } \\
\text { analyzed system (in matrix form) }\end{array}$ & $\begin{array}{l}\text { Step-by-step analysis of the system changes based } \\
\text { on the introduction of single pulses at the top of the } \\
\text { adjacency matrix; identification of the main factors- } \\
\text { levers of influence; the construction of } \\
\text { cognitograms that reflect the scenario development } \\
\text { of the object. }\end{array}$ \\
\hline
\end{tabular}

Cognitive analysis of the information covers two main stages which are aimed at first for defining the goals and objectives of the research; the second, the cognitive structuring of the information about the object of the research of the theoretical and applied nature. Cognitive modeling of the object development (system, phenomenon, process) involves the studying characteristics of the main modeling factors selected by the subject independently on the basis of their own knowledge and experience on the problematic issues of the research object development and/or analyzed views of the expert group and the key issue for the research. These procedures are the basis for the building scenarios for the development of the object of study, providing variability for management decisions in this regard and the alternative to further development of the studied processes and phenomena identified as the factors of cognitive modeling (Croci, 2007).

Cognitive modeling involves the setting impulses on the levers of action which further changes the trend of the situation depending on the given primary conditions (Lambrecht, 2007). The calculation of the set of models at each point of the predicted period should be carried out sequentially, in this case, the calculation results for each model either

Copyright @ 2021 Author(s), published by Vytautas Magnus University. This is an open access article distributed under the terms of the Creative Commons Attribution Non-Commercial 4.0 (CC BY-NC 4.0) license, which permits unrestricted use, distribution, and reproduction in any medium provided the original author and source are credited. The material cannot be used for commercial purposes. 
directly affect the internal indicators of the second models or taken into account when constructing the values of indicators on the following time intervals, the lags are laid down in the specification of models). Such a set of the models in further research provided the opportunity to maintain an adequate idea of the future development of the critical situations at the machine building industry.

The main task of the planning cognitive simulation experiments is to obtain the necessary information about the study system in limited cases (Zadeh).

The model distinguishes between input and output change: $x_{i}, i-1, \ldots k$ and output $y_{j}$, $j-1, \ldots, m . \ldots$ and the factor is the input change and the reaction is the - output. Each factor $x_{i}$ can take one or more values corresponding to the levels during the experiment. A fixed set of levels of factors determines one of the possible states of the system. At the same time, this set represents the conditions for conducting one of the possible experiments. Each fixed set of the factors levels corresponds to a certain point in a rich process which is called a factor space (Antoniuk, 2015).

There is a relationship between the factor levels and the system response which is determined by the ratio:

$$
y_{j}=\grave{\omega}_{j}\left(x_{1}, x_{2, \ldots} x_{k}\right), j=1, \ldots, m
$$

The function $\grave{\omega} \mathrm{j}$, which connects the reaction with the factors, is called the reaction function. The geometric interpretation corresponding to the reaction function is the

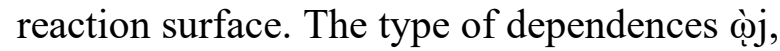
$\mathrm{j}=1, \ldots, \mathrm{m}$ is unknown to the researcher, so the approximate relations are used. The function $\grave{\omega}_{j}$, which links the reaction to the factors is called the reaction function. The geometric interpretation, corresponding to the reaction function represents the reaction surface. The form of the dependences $\grave{\omega}_{j}$, $j=1, \ldots, m$ is unknown to the researcher, therefore, the approximate ratio is used:

$$
\hat{y}_{j}=\grave{\omega}_{j}\left(x_{1}, x_{2}, \ldots x_{k}\right), j=1, \ldots, m
$$

The factors in the conduct of the experience can be controlled and uncontrolled, observable and unobservable, studied and not investigated, quantitative and qualitative, fixed and random (Bantash et al., 2020).

Thus, the risk of a raider take-over of the machine-building enterprise and the length of the period during which it occurs will depend on (Kavun 2013; Zabrodskyi, 2000):

- the number and strength of incoming economic phenomena;

- the degree of the factors impact of the external and internal environment;

- the intensity of the process of the emergence of intermediate economic phenomena;

- the ratio and strength of the intermediate phenomena for each factor of the internal state of a machine-building enterprise;

- the significance of the separate factor within the studied machine-building enterprise and the branch of the national economy.

Based on the system of parameters for assessing the hostile take-over risk of the industrial enterprises and their components (coefficients) and on the assessment of the level of influence of the raiding threats of the industrial enterprises on the Tobin $q$ coefficient as a resultant indicator, the basic conceptual cognitive simulation model of the formation of the risk of raider takeover of the industrial enterprises is (Figure 2).

The ultimate goal of the cognitive simulation model building is the formation methodical and practical proposals for the strength determining and the direction of managerial influences to limit or avoid the threat of raider takeover which will ultimately ensure an increase in the level of the economic security of the industrial enterprise. In the model, the factors are threats for the internal and external environment. According to the proposed stages of constructing a cognitive simulation model for the risk managing of raider take-over of the machine-building enterprise, many factors of influence on the risk of raider take-over have been formed and the strength of their impact for each of the studied machine-building enterprices has been investigated (Hutsaliuk et al., 2020). 


\section{Sciendo}

Management Theory and Studies for Rural Business and Infrastructure Development eISSN 2345-0355. 2021. Vol. 43. No. 1: 151-160

Article DOI: https://doi.org/10.15544/mts.2021.13

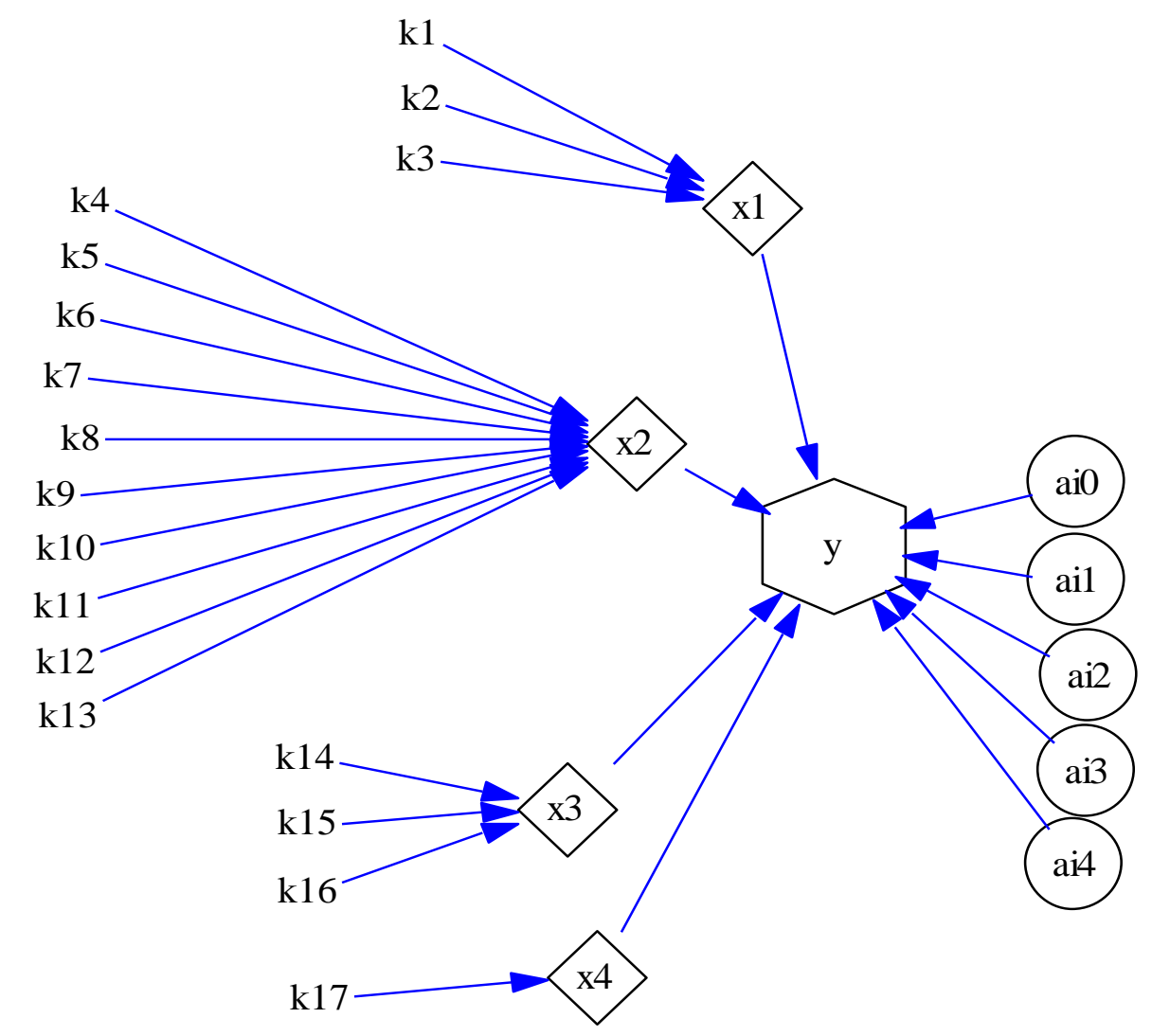

Figure 2. The model of the formation of the risk of hostile takeover of the industrial enterprises on the basis of cognitive imitation technologies

\section{The factors impact on the risk of take-} over

Modern applied scientific works on the problems of the emergence and influence of the environmental factors that are not the object of the enterprise's influence are the subject of close attention and wide scientific and practical discussion, which is reflected in the works (Baltagi, 1995; Jeffrey 2010; Shevchenko, 2014; Wooldridge, 2002). Among the totality of the external factors influencing the risk of raider takeover of the enterprise, the conditions by which they are provided (financial, economic, social) and with which they are interconnected, the study identified three global levels of the environment (Koval, 2018; Yankovyi et al., 2020): 1) world-class factors of influence - the international environment; 2) the factors of influence of the state level - macroenvironment; 3 ) the factors of influence of the regional and sectoral level - Strategic (Pysarevskyi, 2016). Moreover, the certain factors can influence the formation of not one, but several groups of conditions simultaneously. Each separate group of the conditions which are formed under the impact of the factors, can increase or decrease of the raiders risk of the industrial enterprise. But in their totality, the conditions must reinforce or compensate for mutual impact. For example, the poor financial conditions can be offset by favorable social and economic conditions. Many factors of impact on the levels of the external

Copyright (C) 2021 Author(s), published by Vytautas Magnus University. This is an open access article distributed under the terms of the Creative Commons Attribution Non-Commercial 4.0 (CC BY-NC 4.0) license, which permits unrestricted use, distribution, and reproduction in any medium provided the original author and source are credited. The material cannot be used for commercial purposes. 
environment on of raiders risk of the industrial enterprise ( $M i j-j$-th indicator, $i$-th group), investigated in the work, are given in Table 1. Expert methods of information evaluation were used to assess and analyze external factors influencing the risk of raider capture of a machine-building enterprise. The consistency of the obtained expert assessments was checked using the following coefficients: concordance and its significance by the criterion; Spearman's rank correlation; Kendall's rank correlation.

Table 1. Many factors influencing the levels of the external environment on the risk of unpredictable actions of raiders take-over industrial enterprises

\begin{tabular}{|c|c|}
\hline Environmental level & Influence factor \\
\hline \multirow[t]{2}{*}{$\begin{array}{l}\text { International } \\
\text { environment }\end{array}$} & $\begin{array}{l}\text { The impact of the development tendencies of the international stock market on the results of the } \\
\text { industrial enterprises activity (M11) }\end{array}$ \\
\hline & $\begin{array}{l}\text { The impact of the level of investment attractiveness of domestic industrial enterprises for foreign } \\
\text { investors (M12) }\end{array}$ \\
\hline \multirow[t]{4}{*}{ Macro Environment } & The impacy of the stock market on the performance of the industrial enterprises(M21) \\
\hline & The impact of the foreign exchange market on the results of industrial enterprises (M22) \\
\hline & The impact of the money market on the results of industrial enterprises (M23) \\
\hline & The impact of the credit market on the results of the industrial enterprises activity of (M24) \\
\hline \multirow{4}{*}{$\begin{array}{l}\text { Mesoenvironment } \\
\text { (region, industry) }\end{array}$} & The impact of investment activity in the region on the performance of industrial enterprises (M31) \\
\hline & The impact of the economic development parameters of the region (M32) \\
\hline & The impact of crime on the result of industrial enterprises (M33) \\
\hline & The impact of the local government support for industrial enterprises (M34) \\
\hline
\end{tabular}

The task of the second stage of modeling through the use of cognitive simulation technologies involves determining the relationships between the studied factors, their nature, level and strength of influence. To implement a set of the tasks, the method of analysis of hierarchies (Analytic Hierarchy Process) is used, which allows to implement the procedure of making and implementing management decisions. The general task of decision-making is a step-by-step procedure of forming a certain set of alternatives and selecting a certain subset or a certain alternative on the basis of selection criteria or functions. The method of hierarchy analysis consists of procedures for the synthesis of multiple judgments, the calculation of the priority of criteria and finding appropriate alternative solutions. The results of the assessment of the impact of environmental factors on internal threats and the risk of raider take-over of the enterprise are given in Table 2-6. The Table 2 shows the levels of the enterprise environment that affect the level of risk of its raider take-over.

Table 2. Matrix of pairwise comparisons of the levels of the enterprise environment by the level of influence on the risk of raider capture

\begin{tabular}{|c|c|c|c|}
\hline Level of environment & $\begin{array}{c}\text { International } \\
\text { environment }\end{array}$ & $\begin{array}{c}\text { Macroenvironment } \\
\text { (state) }\end{array}$ & $\begin{array}{c}\text { Mesoenvironment } \\
\text { (region, industry) }\end{array}$ \\
\hline International environment & 1 & & \\
\hline Macroenvironment (state) & - & 1 & \\
\hline Mesoenvironment (region, industry) & - & - & 1 \\
\hline
\end{tabular}

It is necessary to make the estimates of the impact strength of each type of environment on the level of the risk on the following scale (Table 3). The grades are set as follows: if the environment in the row has a greater impact than in the column then in the darkened cell at the intersection of these two types of environment is set the number from 1 to 9 according to the rating scale; in the case of the predominance of the force of the medium placed in the column over the force of the medium in the row, the inverse estimate is given in the form of a common fraction. 


\section{Sciendo}

Management Theory and Studies for Rural Business and Infrastructure Development eISSN 2345-0355. 2021. Vol. 43. No. 1: 151-160

Article DOI: https://doi.org/10.15544/mts.2021.13

The table 4-6 shows the factors of the international, macro-environment and mesoenvironment of the enterprise which affect the level of risk of its raider take-over. It is necessary to rank the factors according to the importance level for the relevant environment according to the table. $3 \mathrm{fpr}$ scale.

Table 3. Scale of the relative importance of alternatives

\begin{tabular}{|c|c|}
\hline Importance score & Definition \\
\hline 1 & Equal importance \\
\hline 3 & Moderate advantage \\
\hline 5 & Significant advantage \\
\hline 7 & Strong advantage \\
\hline 9 & Very strong advantage \\
\hline $2,4,6,8$ & Intermediate solutions \\
\hline
\end{tabular}

Tab. 4. Matrix of pairwise comparisons of the factors of the international environment of the enterprise on the level of impact on the raider risk

\begin{tabular}{|c|c|c|}
\hline $\begin{array}{c}\text { Factors of the international environment } \\
\text { of the enterprise }\end{array}$ & $\begin{array}{c}\text { The impactof the development } \\
\text { tendencies of the international stock } \\
\text { market on the results of the industrial } \\
\text { enterprises activity (M11) }\end{array}$ & $\begin{array}{c}\text { The impact of the level of investment } \\
\text { attractiveness of domestic industrial } \\
\text { enterprises for foreign investors } \\
\text { (M12) }\end{array}$ \\
\hline $\begin{array}{c}\text { The impactof the development tendencies } \\
\text { of the international stock market on the } \\
\text { results of the industrial enterprises } \\
\text { activity (M11) }\end{array}$ & 1 & - \\
\hline $\begin{array}{c}\text { The impact of the level of investment } \\
\text { attractiveness of domestic industrial } \\
\text { enterprises for foreign investors (M12) }\end{array}$ & - & \\
\hline
\end{tabular}

Table 5. Matrix of pairwise comparisons of the factors of the macroenvironment of the enterprise on the level of impact on the raider risk

\begin{tabular}{|l|l|l|l|l|}
\hline $\begin{array}{l}\text { Factors of the } \\
\text { macroenvironment of the } \\
\text { enterprise }\end{array}$ & $\begin{array}{l}\text { The impacy of the } \\
\text { stock market on the } \\
\text { performance of the } \\
\text { industrial } \\
\text { enterprises(M21) }\end{array}$ & $\begin{array}{l}\text { The impact of the } \\
\text { foreign exchange } \\
\text { market on the results } \\
\text { of industrial } \\
\text { enterprises (M22) }\end{array}$ & $\begin{array}{l}\text { The impact of the } \\
\text { money market on } \\
\text { the results of } \\
\text { industrial } \\
\text { enterprises (M23) }\end{array}$ & $\begin{array}{l}\text { The impact of the } \\
\text { credit market on the } \\
\text { results of the } \\
\text { industrial enterprises } \\
\text { activity of (M24) }\end{array}$ \\
\hline $\begin{array}{l}\text { The impacy of the stock } \\
\text { market on the performance } \\
\text { of the industrial } \\
\text { enterprises(M21) }\end{array}$ & 1 & & 1 & \\
\hline $\begin{array}{l}\text { The impact of the foreign } \\
\text { exchange market on the } \\
\text { results of industrial } \\
\text { enterprises (M22) }\end{array}$ & - & - & & 1 \\
\hline $\begin{array}{l}\text { The impact of the money } \\
\text { market on the results of } \\
\text { industrial enterprises (M23) }\end{array}$ & - & & & \\
\hline $\begin{array}{l}\text { The impact of the credit } \\
\text { market on the results of the } \\
\text { industrial enterprises } \\
\text { activity of (M24) }\end{array}$ & & & & \\
\hline
\end{tabular}

Copyright $\odot 2021$ Author(s), published by Vytautas Magnus University. This is an open access article distributed under the terms of the Creative Commons Attribution Non-Commercial 4.0 (CC BY-NC 4.0) license, which permits unrestricted use, distribution, and reproduction in any medium provided the original author and source are credited. The material cannot be used for commercial purposes. 


\section{Table 6. Matrix of pairwise comparisons of the factors of the mesoenvironment of the enterprise on the level of impact on the raider risk}

\begin{tabular}{|l|l|l|l|l|}
\hline $\begin{array}{l}\text { The factors of the } \\
\text { mesoenvironment of the } \\
\text { enterprise }\end{array}$ & $\begin{array}{l}\text { The impact of } \\
\text { investment activity in } \\
\text { the region on the } \\
\text { performance of } \\
\text { industrial enterprises } \\
\text { (M31) }\end{array}$ & $\begin{array}{l}\text { The impact of the } \\
\text { economic } \\
\text { development } \\
\text { parameters of the } \\
\text { region (M32) }\end{array}$ & $\begin{array}{l}\text { The impact of crime } \\
\text { on the result of } \\
\text { industrial enterprises } \\
\text { (M33) }\end{array}$ & $\begin{array}{l}\text { The impact of the } \\
\text { local government } \\
\text { support for } \\
\text { industrial } \\
\text { enterprises (M34) }\end{array}$ \\
\hline $\begin{array}{l}\text { The impact of investment } \\
\text { activity in the region on the } \\
\text { performance of industrial } \\
\text { enterprises (M31) }\end{array}$ & 1 & & 1 & - \\
\hline $\begin{array}{l}\text { The impact of the economic } \\
\text { development parameters of the } \\
\text { region (M32) }\end{array}$ & - & - & - & - \\
\hline $\begin{array}{l}\text { The impact of crime on the } \\
\text { result of industrial enterprises } \\
\text { (M33) }\end{array}$ & - & - & & - \\
\hline $\begin{array}{l}\text { The impact of the local } \\
\text { government support for } \\
\text { industrial enterprises (M34) }\end{array}$ & & & & - \\
\hline
\end{tabular}

Thus, expert procedures based on the method of hierarchy analysis allowed to take into account the hidden relationships between indicators through the use of experience, knowledge and intuition of experts in the subject area and to form a block diagram of cause-and-effect relationships of elements of the research process.

The generalized information on the level of influence of the international environment, macro- and meso-environment on internal threats of raider risk of the industrial enterprise allows to draw the following conclusions: the factors of meso-environment $(0,45)$ have the greatest influence on the parameters of raider take-over. In the second place in terms of the influence level are the factors of the macroenvironment $(0,3)$, the least the influence are the factors of the international environment $(0,25)$, which means the dependence of the risk of raider take-over primarily on the situation with protection of the property rights at the regional level of the sphere in the state. The identified patterns of the influence of international, macro-environment and meso-environment of the enterprise on the level of risk of raider take-over allow to build a cognitive simulation model management of raider risk of the industrial enterprises taking into account the significant factors of influence.

The cognitive simulation model is aimed at the formation methodical and practical proposals $\mathrm{s}$ for the determining of managerial influences to limit or eliminate threats of raider take-over, which will ultimately increase the level of economic security of the machine-building enterprises (Bublyk, Koval, Redkva, 2017; Vivchar, Redkva, 2018).

\section{Conclusion}

The article proposes the approaches to modeling the possibility of raider take-over based on the use of cognitive simulation technologies. The proposed algorithm allows not only to assess and analyze the factors, parameters and components of the raider suitability of the enterprise, but also to propose management measures aimed at the risk preventing of raider take-over of the industrial enterprise.

Among the set of the external factors influencing the risk of raider take-over of the enterprise, the conditions under which they are provided (financial, economic, social) and with which they are interrelated, the study identified three global levels of environment: international, macroeconomic, mesoenvironment (regional and sectoral).

It is emphasized that the factors can affect the formation of not one but the several groups of the conditions simultaneously, and each group of conditions formed under the impact of the factors may have a reinforcing or compensating interaction on the raider risk of the industrial enterprises. 


\section{S sciendo}

\section{Management Theory and Studies for Rural Business and Infrastructure Development}

eISSN 2345-0355. 2021. Vol. 43. No. 1: 151-160

Article DOI: https://doi.org/10.15544/mts.2021.13

The proposed set of the tools allows you to analyze the nature, level and strength of the impact of environmental factors on the risk of raider take-over of the industrial enterprise. The implementation of a set of tasks to assess the impact of environmental factors on internal threats and the risk of raider take-over of the enterprise based on the method of hierarchy analysis revealed that the greatest influence on the parameters of raider take-over threats have factors of mesoenvironment $(0,45)$ and macroenvironment $(0,3)$. The factors of the international environment have the least influence $(0,25)$, which means that the risk of raider take-uver depends on the situation with the protection of the property rights at the state and regional levels. The results obtained may be to the particular practical importance to the business owners and managers and anyone who are interested in preventing threats of raider rake-over.

Further prospects of the research are to develop the scientific and practical recommendations for determining the strength and direction of the managerial influences to ensure the economic security of industrial enterprises to counter raiding.

\section{References}

Antoniuk, O. P. (2015). Justification of the choice of model parameters based on information criteria. Ekonomichnyi prostir, 95, 255-262.

Baltagi Badi, H. (1995). Econometric Analysis of Panel Data. New York: John Wiley Sons, Inc.

Bantash, A., Koval, V., Bashynska, M., \& Kozlovtseva, V. (2020). Balanced territorial economic development in the conditions of providing stability of human resources management. Economics. Ecology. Socium, 4(3), 58-66.

Bublyk, M., Koval, V., \& Redkva, O. (2017). Analysis impact of the structural competition preconditions for ensuring economic security of the machine building complex. Marketing and Management of Innovations, (4), 229240. doi:10.21272/mmi.2017.4-20

Croci, E. (2007). Corporate Raiders, Performance and Governance in Europe. European Financial Management, 13(5), 949-978.

Derevyanko B., Pashkov, Turkot O., Zahrisheva N. \& Bisiuk O. (2020). Addressing the issue of corporate raiding in Ukraine. Problems and Perspectives in Management, 18(1), 171-180.

Dreher, A., \& Schneider, F. (2010). Corruption and the Shadow Economy: an Empirical Analysis. Public Choice, 144(1), 215-238.

Heets, M., Kyzym, M., Klebanova, T., Cherniak, O. (2006). Modeling of economic security: state, region, enterprise. Kh. VD INZhEK.

Hutsaliuk, O., Koval, V., Tsimoshynska, O., Koval, M., Skyba, H. (2020). Risk Management of Forming Enterprises Integration Corporate Strategy. TEM Journal, 9(4), 1514-1523. https://doi.org/10.18421/TEM94-26

Ilkova, N., Rynkevych, N. (2018). External Conditions of Bankruptcy Institute Functioning in the Economy of Ukraine. Economics. Ecology. Socium, 2, 1-10.

Jeffrey, M. (2010). Wooldridge. Econometric analysis of cross section and panel data. Cambridge; Massachusetts; London; England: The MIT press.

Kavun, S., Čaleta, D., Vršec, M., Brumnik, R. (2013). Estimation of the Effectiveness and Functioning of Enterprises in Boards of Co prorate Security. European Journal of Scientific Research, 104(2), 304-323.

Koval, V. (2018). State regulation of energy security in national economy. Economics, Ecology, Socium, 2(3), 57-64. https://doi.org/10.31520/2616-7107/2018.2.3-6

Koval, V., Prymush, Y., \& Popova, V. (2017). The influence of the enterprise life cycle on the efficiency of investment. Baltic Journal of Economic Studies, 3(5), 183-187. doi:10.30525/2256-0742/2017-3-5-183-187

Kuzmynchuk, N. V. (2018). Economic security in the system of state regulation of entrepreneurship: the institutional aspect. Adaptyvne upravlinnia: teoriia i praktyka, 5(10).

Lambrecht, B. (2007). Theory of Takeovers and Disinvestment. The Journal of Finance, 2, 809-845.

Liashenko, O. M. (2011). Conceptualization of management of economic security of the enterprise. Luhansk.

Copyright (C) 2021 Author(s), published by Vytautas Magnus University. This is an open access article distributed under the terms of the Creative Commons Attribution Non-Commercial 4.0 (CC BY-NC 4.0) license, which permits unrestricted use, distribution, and reproduction in any medium provided the original author and source are credited. The material cannot be used for commercial purposes. 
Momot, T. V. (2015). Estimation of influence of parameters of threats of raider capture on an indicator of market value of the machine-building enterprise. Problemy ekonomiky, 4, 309-319.

Nazarova, K., Hordopolov, V., Kopotiienko, T., Miniailo, V., Koval, V., \& Diachenko, Y. (2019). Audit in the state economic security system. Management Theory and Studies for Rural Business and Infrastructure Development, 41(3), 419-430.

Pysarevskyi, M. I. (2016). Analytical aspect of risk assessment of raider capture of machine-building enterprises. Skhidna Yevropa: ekonomika, biznes ta upravlinnia, 2, 313-317.

Ryzhov, A. P. (1998). Elements of fuzzy set theory and fuzzy measurements. Moscow Dialogue-MSU. 73, 66-79.

Shevchenko, N. H. (2014). Modeling using panel data. Naukovi zapysky KDPU. Seriia: Matematychni nauky,

Tamosiuniene, R., Demianchuk, M., Koval, V. (2019). State Regulation of Bankruptcy Relations in the National Economy. Economics. Ecology. Socium, 3 (4), 19-27.

The Presidential Office of Ukraine (2020). Decree of the President of Ukraine «On the decision of the National Security and Defense Council of Ukraine of September 14, 2020» On the National Security Strategy of Ukraine».

Varnaly, Z. S. (2011). Economic security of Ukraine: problems and priorities of strengthening. Kyiv: Knowledge of Ukraine.

Vivchar, O., \& Redkva, O. (2018). Analysis of indicators impact on economic security of enterprises in the context of socio-humanitarian components. Economics, Ecology, Socium, 2(3), 65-74. https://doi.org/10.31520/2616-7107/2018.2.3-7

Wooldridge, J. M. (2002). Econometric Analysis of Cross Section and Panel Data. MIT Press.

Yankovyi, O., Koval V., Trokhymets O., Karpenko M., Matskevich Y. (2020). Economic assessment of investment on the basis of production functions. Turismo: Estudos \& Práticas, 2.

Zabrodskyi, V. A. (2000). Property, economic security and the state. Ekonomichna kibernetyka, 3-4, 58-63. Zadeh, L. (1965). Fuzzy Sets. Information and Control, 8. 338-353. 